\title{
TERAPI BAKTERIOFAGA: BISAKAH SEBAGAI ALTERNATIF PENGGANTI ANTIBIOTIKA PADA AKUAKULTUR?
}

\author{
Angela Mariana Lusiastuti* \\ *) Pusat Riset Perikanan Budidaya, Jakarta
}

\begin{abstract}
ABSTRAK
Kemoterapi merupakan metode efektif dan cepat untuk mengobati dan mencegah infeksi bakterial, tetapi penggunaan yang terlalu sering dapat menyebabkan munculnya strain bakteri yang resisten terhadap antibiotika. Bakteriofaga dapat digunakan sebagai kandidat agen terapi untuk infeksi bakterial. Bagaimana efek protektif faga melawan infeksi bakterial dan bagaimana potensinya sebagai phage therapy pada akuakultur dibahas di sini.
\end{abstract}

\section{KATA KUNCl: resistensi, terapi faga, akuakultur}

\section{PENDAHULUAN}

Terapi pada penyakit ikan dapat menggunakan banyak cara, (1) Terapi melalui aktivitas reguler sehari-hari seperti misalnya meningkatkan atau menurunkan gerak ikan secara fisik, memperluas atau mengurangi swimming area, menghilangkan atau menambah objek atau dekorasi pada tangki atau akuarium, dan meningkatkan aliran air sehingga memperkuat gerakan renang.

Perlakuan-perlakuan tersebut di atas jarang digunakan sebagai metode terapi yang sesungguhnya, tetapi lebih banyak ditujukan untuk memperbaiki sirkulasi darah, menghilangkan zat toksik dari dalam tubuh atau meningkatkan respirasi dan mencegah melekatnya parasit pada tubuh.

Jenis terapi lain adalah (2) Fisioterapi menggunakan panas dengan cara meningkatkan suhu yang dapat mempercepat siklus hidup organisme patogen, sehingga obat dapat bekerja pada stadium tertentu dari siklus hidup organisme tersebut. Sebaliknya dengan menurunkan suhu maka dapat memperlambat siklus hidup agen patogen sampai terapi memberikan efek yang diharapkan. Terapi suhu dingin dengan mengapungkan bekuan es digunakan dalam kondisi panas berlebih (over heated) untuk mencegah terjadinya anoxia dan kerusakan otak akibat stroke panas. Kondisi seperti exopthalmus pada ikan dapat diatasi dengan fisioterapi meletakkan ikan di bawah lampu yang memancarkan sinar ultra violet selama beberapa jam setiap hari.

Selain fisioterapi, (3) Psikoterapi juga dapat digunakan sebagai terapi pada ikan seperti memberikan dekorasi tempat persembunyian atau pemberian tanaman spesifik agar ikan terhindar dari shok anafilaktik atau trauma jaringan akibat benturan dengan objek solid atau dinding kaca. Contoh psikoterapi lain adalah dengan mematikan lampu yang memungkinkan ikan dapat beristirahat dalam gelap atau dengan meletakkan tabir opaque sekitar tangki atau akuarium yang dibutuhkan untuk penyembuhan terhadap shok akut. (4) Tindak pembedahan (surgery) biasa dilakukan pada permukaan tubuh ikan, seperti membuang parasit eksternal dengan forsep atau memotong sirip ikan yang luka. Sedangkan, internal surgery pada kavitas visceral dan organ dalam sering dilakukan secara eksperimental. Operasi tumor tidak umum dilakukan, tetapi insisi nodul akibat limfosistis penyakit viral merupakan satu-satunya cara terapi. (5) Terapi diet atau nutrisional juga merupakan aspek terapi tetapi seringkali dianggap sebagai cara dan tindak pencegahan untuk memperbaiki kondisi akibat penyakit. Penyakit nutrisi terutama avitaminosis merupakan penyebab utama turunnya resistensi immun tubuh terhadap organisme patogen. (6) Manajemen lingkungan dapat juga sebagai terapi terutama untuk manajemen kualitas air baik secara fisik, kimia, maupun mekanis. Sistem filter yang sesuai dan dikelola dengan baik dengan atau tanpa karbon atau charcoal termasuk di dalamnya untuk mencegah dan menghambat penyebaran penyakit. Menurut Herwig (1974), filter earth diatomaceous yang terdiri atas granul karbon aktivasi dapat mengabsorbsi beberapa jenis bakteri. Contoh lain terapi manajemen lingkungan adalah penanaman semacam rumput-rumputan pada kolam atau bilah batang bambu di dasar kolam yang memudahkan ikan untuk menggaruk tubuhnya untuk menghilangkan parasit yang menempel.

Jenis-jenis terapi yang lain seperti imunisasi, terapi hormon ataupun profilaksi tidak dibahas secara detail, tetapi semuanya ditujukan untuk menghilangkan atau mengurangi rasa sakit, memperbaiki kondisi supaya sehat dan meningkatkan kualitas hidup ikan. 
Akuakultur saat ini menjadi kegiatan ekonomi yang penting dan menghadapi kendala yang mampu menimbulkan kerugian ekonomis yang besar yaitu penyakit yang disebabkan bakteri patogen. Di awal perkembangan akuakultur, upaya yang dilakukan adalah menggunakan antibiotik sebagai upaya kemoterapi untuk menghilangkan penyakit dan dipraktekkan secara intensif bahkan penggunaannya berlebihan. Peningkatan penggunaan antibiotik pada akuakultur malah diikuti oleh bertambahnya penyakit patogenik dan seringkali hal ini dikaitkan dengan meningkatnya resistensi bakteri patogen. Kekhawatiran pun muncul dari aplikasi antibiotik pada ikan konsumsi terhadap manusia.

\section{Mekanisme Resistensi}

Sejalan dengan perkembangan dan penggunaan antibiotika, banyak bukti, dan laporan yang menyatakan bahwa bakteri-bakteri patogen menjadi resisten terhadap antibiotika. Hal ini dimungkinkan karena adanya transfer materi genetik (plasmid atau transposon) di antara genus bakteri yang berbeda yang masih memiliki hubungan dekat, meliputi bakteri Escherichia coli, Klebsiella, dan Salmonella.

Pada awalnya, problema resistensi bakteri dapat dipecahkan dengan adanya penemuan golongan baru dari antibiotika, seperti makrolida dan glikopeptida, juga dengan modifikasi kimiawi dari antibiotika yang sudah ada. Namun, tidak ada jaminan bahwa pengembangan antibiotika baru dapat mencegah kemampuan bakteri patogen menjadi resisten.

Antibiotika B-laktam adalah contoh antibiotika yang banyak diresepkan ternyata menemui problema resistensi khususnya pada bakteri gram negatif sedangkan sefalosporin yang merupakan antibiotika beta-laktam generasi keempat, terbukti menimbulkan resistensi yang diperantarai oleh plasmid, yang merupakan bagian luar kromosom yang mampu bereplikasi menghasilkan betalaktamase dengan spektrum luas (Sumarsono, 2002).

Perkembangan lain adalah munculnya resistensi ganda (multiple resistence) akibat transfer sambung menyambung dari plasmid. Escherichia coli 0157:H7 yang diisolasi dari limbah cair rumah potong ayam di beberapa lokasi di Jabotabek ternyata sudah resisten terhadap sedikitnya lima jenis antibiotika (Lusiastuti, 1996). Masalah resistensi akibat pemakaian kemoterapi merupakan problem yang serius di Jepang, yang sudah meliputi 25 jenis antibiotika yang sekarang digunakan pada sektor perikanan (Kusuda \& Kawai, 1998).

Bakteri memiliki seperangkat cara untuk beradaptasi terhadap lingkungan yang mengandung antibiotika.
Mekanisme resistensi pada bakteri meliputi mutasi, penghambatan aktivitas antibiotika secara enzimatik, perubahan protein yang merupakan target antibiotika, perubahan jalur metabolik, efluks antibiotika, perubahan pada porin channel, dan perubahan permeabilitas membran.

Berbagai solusi diupayakan antara lain vaksinasi, teknologi budidaya yang lebih baik, Cara Budidaya Yang Baik (CBIB) membawa dampak positif pada perkembangan akuakultur.

Penggunaan probiotik yang bekerja melalui mekanisme tertentu untuk melawan patogen, saat ini dipandang sebagai langkah alternatif. Beberapa tahun terakhir probiotik yang biasa digunakan pada manusia dan hewan mulai diaplikasikan pada bidang akuakultur (Balca'zar et al., 2006).

Mekanisme aksi probiotik antara lain melalui kompetisi eksklusif terhadap bakteri patogen (contoh: Pseudomonas 12 terhadap beberapa bakter Vibrio patogen udang), sebagai sumber nutrien dan kontribusi enzim pada pencernaan ikan (contoh: Clostridium sp.), penyerapan material organik dengan probiotik sebagai mediatornya, serta peningkatan imunitas ikan terhadap patogen.

Probiotik masih memerlukan penelitian lebih lanjut untuk mengetahui mekanisme kerja dan pengaruhnya secara in vivo, pengembangan teknologi molekular untuk seleksi probiotik dan pemahaman kinerja, komposisi serta fungsinya.

\section{Bakteriofaga: jalan alternatif lain yang dapat diambil}

Alternatif lain yang mungkin bisa digunakan untuk terapi infeksi bakterial adalah penggunaan bakteriofaga yang merupakan virus yang dapat hidup pada bakteri (Gambar 1).

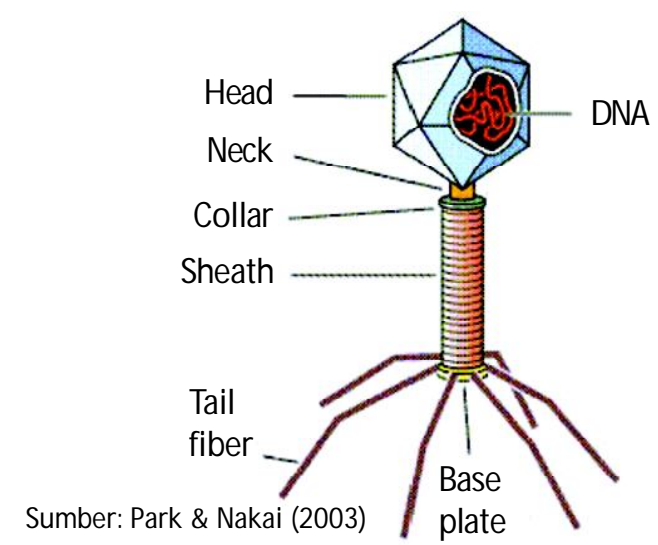

Gambar 1. Bakteriofaga: virus yang hidup pada bakteri 
Setiap jenis hospes bakteri mempunyai faga yang spesifik yang juga bisa ditemukan pada tempat tumbuhnya bakteri tersebut. Faga dapat diseleksi dan diisolasi sebagai antidote dari limbah, feses, tanah, atau tumbuhan. Proses lebih lanjut dari bakteriofaga tergantung dari tujuan terapi. Untuk terapi eksternal, seperti pengobatan luka memerlukan proses sederhana, sedangkan untuk terapi internal maka sampel faga harus dibersihkan dulu dari debris bakteri yang mungkin bersifat toksik.

Tidak seperti antibiotika, bakteriofaga dapat memperbanyak diri (replikasi) dan dapat membatasi dirinya. Replikasi terjadi secara eksponensial sama seperti bakteri sehingga tergantung dari aplikasinya seperti terapi dengan dosis tunggal sangat memungkinkan.

Faga mempunyai daya mutasi dan tingkat replikasi yang tinggi, sehingga dapat berkompetisi dengan bakteri dan akan membatasi perkembangan resistensinya (Park \& Nakai, 2003).

Terapi antibiotika seringkali menyebabkan ketidakseimbangan bakteri flora normal dan menyebabkan masuknya infeksi bakteri sekunder seperti bakteri Pseudomonas sp. atau Clostridium difficile, yang menyebabkan diare parah dan infeksi pada kolon. Sebaliknya, bakteriofaga mempunyai target bakteri yang spesifik dibandingkan antibiotika, sehingga hanya sedikit menyebabkan kerusakan pada flora usus.

\section{Sejarah Bakteriofaga}

Edward Twort \& Felix d'Herelle (1915) menemukan bakteriofaga di Sungai Gangga dan Junna di India. Pada tahun 1921, infeksi kulit yang disebabkan oleh Staphylococcus berhasil diterapi dengan bakteriofaga. Pada tahun 1920-an Institut of Bacteriophage di Rusia memproduksi faga dalam skala besar. Antara tahun 1981 dan 1986, 550 pasien dengan penyakit yang berbeda diterapi menggunakan bakteriofaga. Pada tahun 1997, Amerika mendirikan Georgia Research Institute (GRI) yang memproduksi phage-Bioderm yang merupakan kulit sintetis untuk penyembuhan luka bakar. Produk tersebut banyak digunakan untuk korban perang (Lorch, 1999).

\section{Aplikasi Alternatif dan Masa Depan}

Dalam bidang akuakultur, faga sebagai pembunuh patogen spesifik dapat berperan sebagai agen untuk mengontrol infeksi bakteri pada ikan. Faga dari beberapa bakteri patogen pada ikan, seperti Aeromonas salmonicida, A. hydrophila, Edwardsiella tarda, dan Yersinia rucheri sudah pernah dilaporkan Park et al. (2000).

Nakai \& Park (2002) dan Nakai et al. (1999) melaporkan terapi faga pada infeksi Lactococcus garvieae yang menyebabkan gangguan ekonomi serius pada industri perikanan budidaya ekor kuning di Jepang. Lactococcus garvieae merupakan patogen opportunistik karena merupakan flora normal pada ikan dan lingkungan tempat hidupnya. Sehingga untuk mengendalikan penyakit ini perlu mengurangi faktor stres dengan cara memperbaiki kualitas air yang buruk, kepadatan populasi, dan asupan nutrisi yang kurang memadai. Faga spesifik dari L. Garvieaeyang diisolasi dari ikan sakit dan air laut keramba ikan diidentifikasi sebagai anggota Famili Siphoviridae berdasarkan genom dan morfologinya. Terapi faga dilakukan melalui injeksi intra-peritonial dan administrasi oral secara eksperimental pada ikan jenis ekor kuning yang sakit. Setelah terapi, diperoleh sintasan (100\% $\mathrm{n}=20$ ) pada ikan yang menerima injeksi dibandingkan ikan kontrol tanpa injeksi $(10 \% n=20)$. Proteksi juga diperoleh pada ikan ekor kuning yang diberi faga-pelet. Pemeriksaan L. garvieae pada limpa menunjukkan ikan kontrol masih mengandung bakteri sampai 72 jam atau lebih, sedangkan ikan yang mendapat terapi terdapat bakteri di limpa hanya sampai 48 jam dengan jumlah maksimum $10^{6}$ PFU g ${ }^{-1}$.

Nakai \& Park (2002) juga melaporkan terapi faga pada infeksi Pseudomonas plecoglossicida yaitu bakteri penyebab Haemorrhagic ascites yang merugikan industri perikanan di Jepang sejak awal tahun 1990-an. Antimikroba seperti florfenicol dan sulfisazole yang awalnya digunakan sebagai terapi penyakit yang disebabkan Flavobacterium psychrophilum justru berakibat menimbulkan infeksi P. plecoglossicida yang merupakan patogen opportunistik. Dari bakteri P. plecoglossicida diisolasi dua tipe bakteriofaga dari ikan ayu dan kolam pemeliharaannya. Faga pertama, membentuk plak kecil dan digolongkan dalam famili Myoviridae, sedangkan faga kedua membentuk plak besar dan diklasifikasikan dalam famili Podoviridae (Gambar 2). Ternyata ikan terinfeksi P. plecoglossicida yang diberi faga melalui pakan faga-pelet hidup lebih lama dan tingkat kematian kumulatifnya 22,5\%dibandingkan ikan kontrol yang mati pada hari ke-7 dan dalam waktu dua minggu tingkat kematiannya $65 \%$

Seperti yang sudah diuraikan di atas, terapi faga dapat sebagai terapi alternatif pengganti antibiotika yang dapat diberikan per oral dan merupakan cara efektif pada budidaya perikanan. Terdapat indikasi bahwa faga dapat masuk kedalam tubuh ikan melalui kulit atau insang, karena faga mudah ditemukan pada ginjal setelah dipping dengan larutan faga. Sehingga terapi dipping atau perendaman (bath administration) akan efektif untuk jenis infeksi bakteri yang berkolonisasi pada kulit dan insang. 


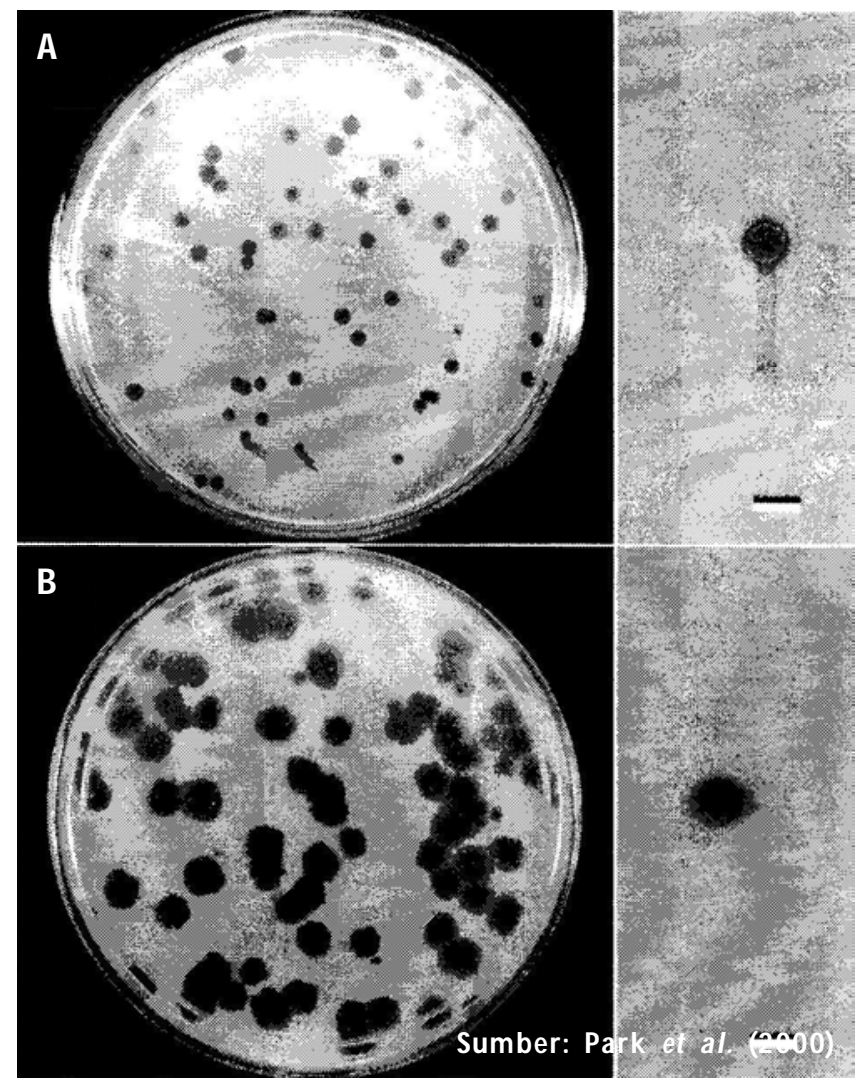

Gambar 2. Plak dari faga P. plecoglossicida dan gambaran elektron mikroskop

(a) Plak kecil, kepala isometri, ekor panjang kontraktil

(b) Plak besar, kepala isometri, ekor pendek

\section{Masalah dalam Terapi dengan Faga}

1. Sensitivitas faga terhadap asam lambung dan abomasum pada ikan-ikan tertentu seperti ikan ekor kuning yang mempunyai level $\mathrm{pH}$ tinggi dalam saluran cernanya, juga pada hewan muda yang mempunyai level pH tinggi pada lambung dan isi abomasum. Faga akan mati jika terkena $\mathrm{pH}$ tinggi.

2. Diperlukan tehnik tertentu atau khusus untuk menyeleksi atau menemukan strain faga yang paling agresif dalam menimbulkan efek terapi. Sebab apabila secara in vivo, faga mempunyai aktivitas yang tinggi maka dapat tahan hidup dalam waktu yang lama.

3. Spesifisitas host yang pendek merupakan kerugian dari terapi yang lebih mengarah kepada strain-spesifik daripada spesies-spesifik dan menyebabkan sulitnya membuat faga dengan berbagai varian yang berbeda dan dalam jumlah banyak.

4. Perlu diwaspadai munculnya bakteri yang resisten terhadap faga seperti halnya problem pada kemoterapi seperti yang terjadi pada kultur L. garvieae dan P. plecoglossicida yang resisten terhadap faga. Tetapi pada penelitian Nakai \& Park (2002) isolat L. garvieae dan P. plecoglossicida yang diisolasi dari ikan mati selama penelitian masih tetap peka terhadap faga. Lebih jauh, varian P. plecoglossicida yang resisten terhadap faga yang ditumbuhkan in vitro kehilangan virulensinya untuk jenis ikan tertentu. Pengendalian menggunakan faga yang telah sukses dilakukan untuk memberantas infeksi sistemik E. Coli (018:K1:H7) dan penyebab diare pada anak sapi yang disebabkan enteropatogenik E. Coli $(09: K 30,99)$ dan (020:K101,987P), hanya tipe $\mathrm{K}$ - yang bersifat kurang virulen yang muncul sebagai organisme resisten terhadap faga sehingga komponen permukaan yang berhubungan dengan virulensi bakteri diduga sebagai reseptor untuk perlekatan faga dan konsekuensinya varian organisme virulen yang resisten terhadap faga tidak lagi bersifat patogenik.

5. Perlu dipikirkan kemungkinan dihasilkannya antibodi yang dapat menetralisasi faga sebagai akibat pemberian faga secara per oral maupun par enteral yang dapat menimbulkan kesulitan dalam terapi faga memberantas infeksi kambuhan. Hal ini dikhawatirkan karena pernah dilaporkan adanya antibodi penetral faga terhadap entero patogenik E. coli pada serum manusia, sapi, babi, dan kolustrum. Antibodi penetral ini dirangsang setelah faga diberikan secara per oral dan melalui par enteral dan diperoleh level antibodi yang tinggi (Nakai \& Park, 2002). Tetapi dalam penelitian Nakai \& Park (2002) tidak terdeteksi antibodi penetral faga pada ikan ekor kuning dan ikan ayu yang mendapat terapi pakan faga selama lebih dari 7 hari (dengan dosis $10^{7}$ PFU ikan-1) dan menerima injeksi intramuskuler cairan faga 4 kali per minggu dengan dosis $10^{9}$ PFU ikan ${ }^{-1}$.

6. Kemungkinan problem lain adalah adanya risiko pertukaran materi genetik antar faga dan bakteri, sebagai misal tranduksi atau konversi faga dan membuat virulensi bakteri meningkat.

Faga tidak dapat sebagai panacea of medicine, tetapi terapi faga dapat sebagai momentum karena riset antibiotik akan selesai dan berhenti. Faga yang sudah terseleksi dengan baik dapat digunakan untuk pencegahan penyakit dan dapat sebagai alternatif bagi negara-negara berkembang.

\section{DAFTAR PUSTAKA}

Balca'zar J.L., I. De Blas, I.R. Zarzuela, D. Cunningham, D. Vendrell, and J.L. Mu'zquiz. 2006. The Role of Probiotics in Aquaculture. Vet. Microb. 114:173- 186. 
Herwig, N. 1974. Handbook of Drugs and Chemicals Used in Treatment of Fish Diseases. Charles Thomas Publisher Springfield. Illinois.

Kusuda, R. dan K. Kawai. 1998. Bacterial Diseases of Cultured Marine Fish in Japan. Fish Pathol. 33: 221227.

Lorch, A. 1999. Bacteriophages: An Alternative to Antibiotics? Australasian Biotech. 9(4):265- 269.

Lusiastuti, A.M. 1996. Pengaruh Klorin Terhadap profil Resistensi Antibiotika Bakteri Coliform dan E. coli 0157:H7 dari Limbah Cair Rumah Potong Ayam. Media Kedokteran Hewan. Vol. 11 No. 1.

Nakai, T., R. Sugimoto, K.H. Park, S. Matsuoka, K. Mori, T. Nishioka, and K. Maruyama. 1999. Protective Effects of Bacteriophage on Experimental Lactococcus garvieae in Yellowtail. Dis. Aquat. Org. 37: 33-41.
Nakai, T. and S.C. Park. 2002. Bacteriophage Therapy of Infectious Diseases in Aquaculture. Res. In Microbiol. 153: $13-18$.

Park, S.C., I. Shimamura, M. Fukunaga, K.I. Mori, and T. Nakai. 2000. Isolation of Bacteriophages Spesific to a Fish Pathogen. Pseudomonas plecoglossicida, as a Candidate for Disease Control. App. and Environ. Microb. 66(4): 1,416-1,422.

Park, S.C. and T. Nakai. 2003. Bacteriophage Control of Pseudomonas plecoglossicida Infection in Ayu Plecoglossus altivelis. Dis. Aquat. Org. 53: 33-39.

Sumarsono, T. 2002. Seputar Masalah Resistensi Antibiotika. Pikiran Rakyat Minggu, 28 Juli 2002. 